Paedagogia Christiana

2/46 (2020) - ISSN 1505-6872

DOI: http://dx.doi.org/10.12775/PCh.2020.018

Gillian Simpson*

ORCID: 0000-0003-4653-289X

York, Great Britain

\title{
Beyond the Lonely Learner: Towards an Autoethnographic Method in Studying and Researching Religion
}

\section{Przekraczając osamotnienie ucznia: ku metodzie autoetnograficznej w studiowaniu i badaniu religii}

\begin{abstract}
Being a learner can be lonely and isolating. The academic culture in the UK can leave an individual feeling segregated and alienated both from their peers and, importantly, from their authentic selves, as they scrabble to have their voices heard in an ever-segregating and performative environment. This can detract from a good learning experience, particularly in subjects like religious studies which require a multi-focal approach to learning. Humanistic education theory recognises the need for mutuality and friendship. The theory grew from humanistic psychologists who placed 'I' at the centre of education practices, and led to the rise of Critical Reflection as a means of self-development in many fields of study. This has, in turn, given rise to an increase in self-awareness in learners with the capacity for endless improvement. But it can leave the individual feeling disengaged from their holistic self, as personal and academic learning are separated, with a sense of fragmentation
\end{abstract}

* Gillian Simpson, Senior Lecturer, School of Humanities, Religion \& Philosophy, York St John University, email: g.simpson@yorksj.ac.uk. 
between the subject material and the personal meaning for the individual. So, are there other ways to approach learning which incorporate both the self and the subject matter in a more holistic way? This paper proposes that one possible solution is to develop an autoethnographical approach which allows the individual to engage in the subject material while seeking his/her own truths in those materials. The core ideals of autoethnography allow this by connecting 'personal (insider) experience, insights and knowledge to larger (relational, cultural, political) conversations, contexts and conventions' in order to create 'nuanced, complex, and specific accounts of personal/cultural experience' (Adams et al., 2015, p. 25). The author will challenge canonical ways of conducting research by exploring the possibility of using autoethnography as a means of cultivating dialogue with a learning community, a body of knowledge and with the self, to develop a method for learning religion which allows for a holistic and integrative approach to the individual's own self-understanding, and helps alleviate the loneliness of the learner through learning in ways that are congruent with core values and ideals.

Keywords: education; autoethnography; reflective learning; humanistic education; divided-life; integrated life.

Abstrakt: Bycie uczniem bywa samotne i izolujące. Kultura akademicka w Wielkiej Brytanii może wywoływać w jednostkach poczucie wyizolowania i wyobcowania zarówno od swoich rówieśników, jak i, co ważne, od ich autentycznego ja, gdy starają się, aby ich głos był słyszalny w tym segregującym i performatywnym środowisku. Może to zakłócić proces edukacyjny, szczególnie w przypadku przedmiotów takich jak religioznawstwo, które wymagają wieloogniskowego podejścia do uczenia się. Teoria edukacji humanistycznej podkreśla potrzebę wzajemności i przyjaźni. Teoria ta pochodzi od humanistycznych psychologów, którzy umieścili ja w centrum praktyk edukacyjnych i doprowadzili do uznania krytycznej refleksji za środek samorozwoju w wielu dziedzinach nauki. Doprowadziło to do wzrostu samoświadomości u uczniów ze zdolnością do ciągłego doskonalenia. Z drugiej strony może to skutkować swoistym niezaangażowaniem osoby wobec jej holistycznego ja - jako że osobisty i akademicki rozwój zostają rozdzielone - oraz poczuciem oderwania materiału przedmiotu od jego osobistego znaczenia dla jednostki. Czy są zatem inne sposoby podejścia do uczenia się, które obejmują zarówno osobiste ja, jak i sam przedmiot w holistyczny sposób? Niniejszy artykuł proponuje wypracowanie podejścia autoetnograficznego, które pozwalając jednostce na zaangażowanie się w materiał tematyczny, umożliwia poszukiwanie w nim własnych prawd. Dzieje się tak dzięki podstawowym założeniom autoetnografii, łączącym „osobiste (wewnętrzne) doświadczenie, spostrzeżenia i wiedzę z szerszymi (relacyjnymi, kul- 
turowymi, politycznymi) rozmowami, kontekstami i konwencjami" w celu stworzenia „zniuansowanych, złożonych i specyficznych opisów osobistego/kulturowego doświadczenia" (Adams i in., 2015, s. 25). Autorka rzuci wyzwanie kanonicznym sposobom prowadzenia badań, zgłębiając możliwość wykorzystania autoetnografii jako środka dialogu: ze społecznością uczącą się, z zasobem wiedzy i z samym sobą, aby opracować metodę uczenia się religii, która z jednej strony pozwoli na holistyczne i integracyjne podejście do własnego samorozumienia jednostki, a z drugiej złagodzi osamotnienie ucznia poprzez uczenie się w sposób zgodny z podstawowymi wartościami i ideałami.

Słowa kluczowe: religia; edukacja; autoetnografia; refleksyjne uczenie się; edukacja humanistyczna; podzielone życie; życie zintegrowane.

\section{Introduction}

My own experience of higher education (HE) was of a growing fragmentation of community identity in an environment which tends to value the divided life (individualism and scepticism) over personal meaning. I came back into learning to find out more about a faith which had formed the backbone of my life and yet more and more made no sense in its existing state; I had lost a religious community (or it had lost me). In my initial learning experience of learning Christianity in $\mathrm{HE}$, I found an academic community which was social, open, passionate and personal. However, as I transitioned from learner to tutor, I found an increasing disconnect between student learning and personal meaning-making. I have encountered many lonely students, alienated from both their 'selves' and their learning, and I have continually sought to find a solution to this. My own learning has been peppered with 'light-bulb' moments when engaging with some of the authors you will read about below (in particular Carl Rogers and Thomas Merton) who have inspired me and informed my personal change, and with the additional discovery of autoethnography as an academic method. It is this which I share with you here. My own approach to learning about religion became clear when I discovered autoethnographical research - a relatively new methodology which adopts self-narrative as a research tool in evaluating cultural concerns, or, as Ellis and Bochner (2000, p. 742) described, 'autobiographies that self-consciously explore the interplay of the introspective, personally engaged self with cultural descriptions mediated through language, history, and ethnographic explanation'. This method helped me to differentiate be- 
tween various types of religious learning and to recognise that my struggle to reconcile what I 'knew' from a faith perspective with what I subsequently learned in an academic forum was in fact part of a larger cultural dialogue, both in the field of religious learning and in the larger academic community as a whole. There can be a disconnect between head and heart which academic communities often fail to acknowledge and which leaves the learner feeling isolated, out of step with her own values and norms.

Like my own religious education, much learning about religion takes place within supportive communities. This includes all types of learning, whether informal and experiential in daily life, among friends, family, faith groups, religious communities, or in formal educational settings where academic, social and personal growth is anticipated. Learning about religion in educational settings particularly invites a multi-focal, academic and reflective pedagogy which reveals the social and communal nature of both the subject matter and the learner's own responses. Learning about religion, however, can also be isolating. It can insulate, seclude, separate, set up dissonance and breed unhealthy competition. Research into religious education has indicated that, in secondary education, pupils are most motivated by existential and ethical approaches to religion when knowledge 'evolves via practice, reflection and conversation' in communities of practice using an interpretive approach to the material (O'Grady, 2010, pp. 120-121). This method was also found to have a positive effect on students beginning initial teacher education (Everington, as cited in O'Grady, 2010, p. 123). A great deal of learning in HE however, not least religious studies, is still conducted within a theoretical framework in which 'ideas are kept apart from feelings' (Palmer, as cited in Lantieri, 2001, p. 3). This leads learners to work alone, disengaged from personal, reflective interaction with the subject and living a divided life, with a tendency for poor learning and alienation from both the subject and self as they strive to achieve individual, target-driven results based on these methodologies. In HE, the academic research culture is often portrayed as collaborative and collective, built on communities of knowledge, yet at the same time it can be experienced as a lonely place, with $46 \%$ of researchers and $64 \%$ of $\mathrm{PhD}$ candidates reporting feelings of loneliness (Sibai et al., 2019). Undergraduates, also, often report a crippling sense of loneliness during their degree programmes, not uncommonly leading to dropping out. One of the biggest factors contributing to loneliness is stress, overwhelmingly in relation to 'worries about performance in academic assessments' (Bradley, 2017, p. 38). The emphasis on achievement in HE is substantially associated with academic success, leading to a competitive learning environment and poten- 
tially an insular, isolated approach to working. Competition between peers acts as a driving force and ultimately exacerbates feelings of alienation and loneliness.

This paper will challenge the recognised 'canonical ways of doing research' (Ellis et al., 2010) and other forms of learning as contributing to learner loneliness, and seek to find a different methodology for learning. It will consider the contribution of Macmurray's philosophy of 'self as agent', which recognised the need for mutuality and friendship, for HE learning, and the possibilities and limitations of Carl Rogers' humanistic approach to education and the subsequent development of reflective learning, its opportunities and limitations, as a way of breaking through the barriers of traditional pedagogies to make connections between experience and theory. The possibility of a different, dialogical form of learning will be evaluated for HE generally, and religious studies specifically. It will be based on an autoethnographical methodology grounded in the subjective and the personal in the process of learning, and will relate to Macmurray's personalist philosophy, the humanistic psychology of Rogers and reflective methods of learning and teaching. I will propose that making use of autoethnography in HE can improve learning and reduce the alienation of the learner, from undergraduate work to the highest levels of research, especially (though not exclusively) in relation to religion.

\section{The loneliness of learning}

In the HE environment I am aware of a chasm between academic learning and reflective personal engagement in the field of religious studies. I was fortunate, as I moved between learning about faith in a religious community to more critical engagement in an academic environment, to find a tutor who was both reflective and dialogical, bringing his own experience into the classroom, while paying close and careful attention to the lived experiences of the students. This enabled us to both expand on and critique what we already knew, in an environment that encouraged personal experience as part of the academic method; what I did not know was that this was an early encounter with autoethnography. This type of learning, however, is sadly not the case for many undergraduates and postgraduate researchers who struggle to reconcile their inner values and personal experience with their academic context. 
Weiss (1973) described loneliness as 'a situation in which a person experiences a subjective deficiency of social relationship in a quantitative or qualitative way'. Competition, performance concerns and disengagement from support structures offered by friends and colleagues, can all lead to feelings of isolation in HE. This learning environment is partly a product of the post-Enlightenment values of 'individualism and self-determination', with an emphasis on scepticism, critical attitude and the authority of reason (Bristow, 2017), which also, seemingly, had a resulting effect on support structures:

... the individualistic lifestyle has changed the character of society. The effects can be noticed in personal life, in the dealings between people and in the general social environment. Whereas people used to have a limited number of relatively stable bonds (marriage, family, work, neighbourhood, club life), nowadays there are many relatively fleeting bonds. The fairly small communities in which people used to live have made way for a multiplicity of social bonds within which people have to function. (Hortulanus et al., 2006, p. 4)

These effects are evident in HE, with greater autonomy in the learning environment potentially resulting in isolation and feelings of loneliness both at postgraduate and undergraduate levels.

Sibai et al. (2019) observed that, for postgraduate researchers, pressure to perform can leave no option but to disengage from 'potentially energising relationships with local colleagues and friends'. The fleeting academic bonds made in research may be no substitute for deeper personal and social connections leading to ever-greater isolation and feelings of loneliness. Amongst undergraduates also, the sense of isolation emanating from a mismatch between the expectation and reality of university life is not alleviated in the learning environment. Some undergraduate expectations are met; however, it is also evident that: "the positive affective tone that characterizes their preuniversity expectations is often replaced by feelings that are more negative ... The reality of students' experiences at university is harsher and more stressful than many of them anticipated' (Compas, Wager, Slavin \& Vanatta, as cited in Pancer et al., 2000, p. 39).

This occurs at a time when they are struggling with isolation from pre-university lives and the social bonds in which their personal and academic identities had previously been embedded. University teaching and research methods can exacerbate the problem of isolation with an approach which favours the objective, neutral learner. In both undergraduate, postgraduate and academic communities, little connection is made between the subject and learn- 
ing from and about the self, which can lead to learner absence and a poor learning experience ${ }^{1}$.

One answer is to develop Communities of Writing (CoWs), groups of people 'Who share a concern, a set of problems, or a passion about a topic, and who deepen their knowledge and expertise in this area by interacting on an ongoing basis' (Wenger et al., 2002, p. 4). In a bid to alleviate loneliness in learning, CoWs can provide a space in which the emotional, personal and environmental barriers to research can be expressed and shared (Stone et al., 2010). These are in the form of either field-specific or multidisciplinary groups which can help to develop specific or generic skills, raise awareness of different writing styles and open up the possibility of cross-collaboration between subject areas (Gannon-Leary et al., p. 456). However, the increasing emphasis in HE today is on a form of authenticity and legitimacy which is centred around the creation of capital and the formation of competitive social relations which ensure that 'particular interests, characteristics and identities are accorded recognition and value' (Archer, 2008). For younger academics, their claims to authenticity are shaped not by their life experiences in dialogue with their research area, but by 'their locations and embodied identities within their institutions' (ibidem), as well as their ability to create capital.

\section{The divided life}

The dominance of competitive social relations in HE highlights the question of a potential disconnect between head and heart and the problematical nature of using only the divided life approach to learning. Professor of Performance Studies, Tami Spry, reflecting on her research method based on emotion and poetics, described it as heretical and 'consitut[ing] scholarly treason' (2001, p. 709). She acknowledged, however, the benefit of her methodology, which importantly 'gives shape to social relations' (Langellier, 1999, p. 208), despite the complex and destabilising effect of the method. For Spry, personal narrative performance serves as a validating academic experience, as conventional research canonicity had nothing to offer her:

I have often felt like I was speaking from outside of my body in my professional and personal lives. In fact, for me, academe has always been about speaking

${ }^{1}$ A recent study (Sadeghi Bahmani et al., 2018) showed a correlation between low negative emotional functioning and grade scores. 
from a disembodied head. .... [it] is rather like the headless horseman galloping wildly and uncontrollably to somewhere, driven by profane and unruly emotion, while the head - holder of the Mind - is enshrined under glass in the halls of academe. (Spry, 2001, p. 715)

Her dramatic and evocative reflection on the inappropriateness of conventional, divided-life methodologies in her subject area leads us to reconsider the correlation between the sense of isolation and loneliness experienced by many researchers and the disconnect between head and heart in traditional research. The need for an approach to learning based on a more holistic pedagogy was foreshadowed by John Macmurray (1935). His observations on the meaning of existence presaged the current crisis of loneliness in HE when he asked, 'What other significance can our existence have than to be ourselves fully and completely?'. His acknowledgement of the imperative of 'being ourselves' calls into question the efficacy of an education that is grounded solely in intellectual approaches to material:

Intellectual knowledge tells us about the world. It gives us knowledge about things, not knowledge of them. It does not reveal the world as it is. Only emotional knowledge can do that. The use of the senses as a practical means of getting knowledge is thus not a way of knowing the world at all, but only a way of knowing about it. The wider use of the senses for the joy of living in them, is knowing the world itself in and through emotion, not by means of the intellect. This is not to disparage intellectual knowledge but only to insist that it is meaningless and without significance, apart from the direct sensual knowledge which gives it reality. One cannot really know about anything unless one first knows it. (Macmurray, 1935, p. 22)

For Macmurray, emotional awareness comes through apprehending the world around us. Actions which are limited to the intellect are, in effect, mechanical actions; emotional awareness, he asserts, is what leads to creativity expressed in action (ibidem, pp. 23-24). While I agree with Macmurray, further steps are needed to achieve a learning method which is truly holistic. To develop this further, we need to ask about perceptions of loneliness in a HE environment.

Alienation from the self is a challenge for undergraduates and researchers alike. Vighnarajah and Lim (2018, p. 2) noted that university life involves not only academic activity, but also 'social interactions and psychological developments' which enable a more holistic learning environment. There is, 
however, a disconnect between academic learning and personal human development here. During their studies, students/researchers are often forced to face "conflicts within themselves, as they struggle to adjust their mindset and psychological state throughout the learning process' (Ibidem, p. 4). These issues are rarely addressed in the learning environment and there is relatively little space to explore personal meaning within current academic pedagogies. So, we must return to Macmurray's premise that 'one cannot really know about anything unless one first knows it,' and ask how the sense of isolation and loneliness can be alleviated through encouragement of more holistic teaching and learning practices. This is distinctively challenging in the Natural Sciences, which lend themselves more freely to attempts at 'impartial' observation and 'neutrality.' However, the Arts and Humanities, which explore what it means to be human, are also most often taught in ways which invite divided-life learning that attempts to be 'impartial' and 'neutral', often preventing the researcher from developing a sense of authenticity.

\section{Towards a holistic learning method}

In my own learning I was introduced to a number of seminal thinkers who, for me, reached across the boundaries of academic disciplines and presented opportunities for developing approaches to religious education both from a cross-disciplinary perspective and through a more engaged dialogical approach with my tutors. This began with Carl Rogers, who opened up the concept of freedom of learning, and continued with the work of some of the more recent authors on reflective learning, such as Brockbank and McGill (1998) and Moon (2004), who challenged traditional didactic pedagogies and gave more voice to the student's own experience.

One possibility for developing integrated learning is to challenge the relationship between tutor/supervisor and student/researcher in order to allow learning to be more 'real.' Rogers (1969, pp. 164-166) observed that, for education to be truly effective, a number of core conditions must be demonstrated by the teacher/facilitator which would give learners the freedom to learn without the constraints of traditional academic norms. Freedom is at the heart of Rogers' humanistic approach to education. Referring to Victor Frankl's poignant description of freedom in the Nazi concentration camps in which 'Everything can be taken from a man but one thing: the last of the human freedoms - to choose one's own attitude in any given set of circumstances, to choose one's own way' (Frankl, as cited in Rogers, 1969, p. 269), 
Rogers (ibidem) noted that the meaning of freedom comes from 'within oneself ... from listening sensitively and openly to the complexities of what one is experiencing ... the recognition of a person that he is an emerging process, not a static end product.' The recognition and acceptance of freedom is part of the process whose goal is the 'fully functioning person,' someone who emerges from therapy or 'the best of education' (ibidem, p. 295) as self-enhancing, socialised, creative, ever-changing and ever-developing (Rogers, 1963, p. 26). This relies on an acceptance of some general principles of learning, notably that 'significant learning takes place when the subject matter is perceived by the student as having relevance for his own purposes' (ibidem, p. 158). This acknowledgement that learning must be student-centred and relevant to the learner lends weight to the argument that learning is contextual, and awareness of self is central to the learning process. Failure to recognise this potentially denies the learner the right to the possibility of a holistic education, furthering the potential for isolation and loneliness.

Student-led approaches to teaching based on Rogers' student-centred theory, have made some inroads into the bias towards teacher-focused transmission. In a study at a UK university, students involved in student-led learning noted that they felt more respected, learning was more interesting and exciting, and there was a positive impact on self-confidence (Lea et al., 2003). Research, however, has indicated that, in some instances of student-led learning, 'many institutions or educators claim to be putting student-centred learning into practice, but in reality they are not' (Lea et al., 2003, p. 322). Class sizes can have a detrimental impact; placing a student at the heart of the learning process requires a personal relationship and dialogue with tutors, which in large classes is impossible to achieve, leaving the student feeling abandoned or isolated (O'Neill \& McMahon, 2005, p. 33). The question then remains, whether Rogers' concept of optimal psychological growth is feasible for learners (students and academics) in the current HE climate.

Since Rogers' work in the 1960s, educational theorists Kolb (1975), Schön (1983) and Boud (1985) have adopted a more practitioner-based approach to research. Following Schön's research on 'reflection on,' and 'reflection in' action as a means of alleviating the crisis of confidence that had permeated the professions in the 1970s and 1980s, progress towards developing more reflective methods in $\mathrm{HE}$ has been made. Expanding on this progress, Brockbank and McGill (1998) and Moon (2004) developed approaches to learning which highlighted the importance of transformative education.

Brockbank and McGill developed their theory of emotional learning after it had been established by Rogers $(1969$, p. 105), who regarded the aim of 
education not as the acquisition of knowledge, but the 'facilitation of learning'. They identified the difference between transmittive and transformative learning (Brockbank \& McGill, 1998, p. 52), ${ }^{2}$ the latter of which involved dialogue at the core of the learning experience. Developing Dewey's idea that learning activities must involve both the learner (as teacher) and the teacher (as learner) in dialogue (Dewey, 1916, p. 160), Brockbank and McGill challenged the persistent dualism of 'privileging of mind over body' that exists in $\mathrm{HE}$ and the consequent 'preoccupation with transmission of knowledge, while overlooking process' (1998, p. 30). Attention to process requires the development of a different form of relationship between learner and teacher so that both parties "engage with the reality of the struggle to understand and learn as it happens by constructing their own knowledge with each other' (ibidem, pp. 68-69). They introduce and acknowledge the social and political context of learning which can be counter-productive to personal 'bursts of productive energy and emotion' (Salmon, 1989, as cited in Brockbank \& McGill, 1998, p. 46), and they recognise that in the field of emotion they find 'academia sadly missing'. Emotion is rarely valued in academic life due to 'the premise that intellect was superior to body and that only the mind could be rational, the emotions being untrustworthy' (ibidem). So, for learning in HE to accommodate and make use of emotion, tutors need to engage emotional intelligence and adopt the role of facilitator with an emphasis on relationship and dialogue between teachers and students. This challenges learners to engage 'at the edge of their knowledge and their sense of the self and the world as experienced by them' (ibidem, p. 57). The aforementioned can be achieved through a variety of techniques, including modelling, whereby the learner is able to engage in modelling the teacher, both unintentionally and as an active learning process (ibidem, pp. 64-65) in order to produce an optimum environment for reflection. The learning, however, is still subject-driven, chosen and directed by the tutor, with the process of reflection on learning being modelled in the style of the teacher.

Jennifer Moon drew on the work of Brockbank and McGill to develop a theory of deep and surface learning. Surface learning is indicated by a gen-

2 Transmittive learning is defined as 'that form of teaching which is primarily didactic, one-way transmission of knowledge from the expert teacher to the dependent student learner.' Transformative learning means that 'the learner is encouraged to become a critical thinker according to the standards and requirements of her discipline, as well as recognising the relativity of knowledge, that it is, and continues to be, socially constructed' (Brockbank \& McGill, 1998, pp. 52-53). 
eral intention from the learner to 'absorb' enough information so as to be able to complete a task (Moon, 2004, p. 59), while deep learning is:

... characterised by an intention in the learner to understand the material of learning, seeking the meaning and understanding the ideas in it. The learner who takes a deep approach seeks the underpinning principles and endeavours to relate the material to previous knowledge and understandings. (2004, p. 59)

For Moon, the purpose of deep approaches is 'transformative learning' (ibidem, pp. 84-85) where new knowledge and understanding is generated, which flows out of existing knowledge and contexts. This is the goal of reflective learning - a process of developing and articulating new theories through conscious dialogue about multiple perspectives and ideas. Moon named what she regarded as popular misconceptions about academic reflection which are obstructive to the process, stating that 'emotion is central to the reflective process ... reflection is about 'my own' process (i.e., always in the first person) ... and that some people cannot reflect' (ibidem, p. 88). It is entirely possible, and perhaps even beneficial in some circumstances, to understand academic reflection as a consciously-articulated extension of the academic process in which the researcher uses reflective techniques to deepen the theory being tested. For Moon, depth in reflection requires:

Sophistication in a number of areas of development, in particular, the learner's conception of the structure of knowledge and the notion of knowledge as constructed ... In deep reflection the learner requires the ability to manage emotion, and where appropriate to work with it ... to frame her approach to learning in accordance with her (and given) intentions for the task. (ibidem, p. 100)

For both Moon, and Brockbank and McGill, the goal of academic reflection is to deepen the academic process through self-awareness. In both theories, emotion is acknowledged, but is subjugated as a distraction from the real purpose of developing new extrinsic knowledge. This has, on some HE courses, become standard practice; indeed, recent publications about postgraduate research give useful advice on steps to success, ${ }^{3}$ including a process of reflection and integration. This method, however, focuses on the premise

${ }^{3}$ For example, Tony Greenfield and Sue Greener's edited volume Research Methods for Postgraduates $(1996,2002,2016)$ outlines four steps to success, including 'Reflecting and integrating.' 
that 'Knowledge doesn't exist in a vacuum, and your knowledge only has value in relation to other people's' (Janowitz, as cited in Bourner \& Greener, 2016, p. 10); academic reflection and integration thus involves a process of evaluation of the self:

What you have learned about the process of research, what you could have done differently and what you have learned about yourself, [but the] crucial part of the research process [that will] affect how your research is judged and the impact of your research [is to] reflect on how your research findings relate to current thinking in the field of your research topic. (ibidem)

This form of deductive, objective inquiry employed equally by the Sciences, Social Sciences, and the Humanities, is seen as the norm and pinnacle of research methodology, in which reflection is about testing and amalgamating individual ideas into a larger body of knowledge. Like Brockbank and Moon, Jankowitz saw the reflective process as an important part of the academic process. His observations leave reflection firmly rooted in divided-life research, wholly embedded in subject knowledge and the furthering of expertise in a particular academic field. There is still little room for integrating personal experience, as reflection remains embedded in objectivity and researcher distance. There also remains a disconnect between personal insights and experience, and the subject content; the learner's voice is acknowledged but suppressed - and he/she potentially remains alienated. This form of reflection, while furthering subject engagement, leaves little room for the researcher to embrace Macmurray's (1935) notion of 'being ourselves fully and completely.'

\title{
5. Beyond lonely learning: autoethnography as research method
}

\author{
Autoethnography creates a space for a turn, \\ a change, a reconsideration of how we think, \\ how we do research and relationships, \\ and how we live. (Jones et al., p. 21)
}

For Rogers, the role of the teacher/facilitator is to 'help to elicit and clarify the purposes of the individuals in the class as well as the more general purposes of the group' (Rogers, 1969, p. 164). For the lone researcher, however, 
this must be accessed elsewhere as he/she is often working in physical as well as emotional isolation. The traditional purpose of academic research is to contribute to a body of knowledge and to be heard in the debate pertaining to that knowledge, to seek new 'knowledge and understanding of the world and its processes' and to test 'assumptions and beliefs' (Wisker, as cited in Kasi, 2009, p. 33). This comes, as Einstein noted, through 'passionate curiosity' (Kasi, ibidem). And it was the importance of the concept of 'passionate' curiosity that made me feel that, even with the application of Rogers' methodology and reflective learning approaches, something was still missing for many learners in HE. My observation of students over a number of years has led me to the conclusion that there is still a disconnect which keeps the learner in isolation. From where does that passion emanate and how can it be replicated to enhance both students' engagement and ownership of their learning? What is missing is access to relational and cultural dialogues which allow students to develop both their self-awareness and more complex and nuanced approaches to their studies - dialogues which would give voice to their own personal and cultural experience and form part of the research framework.

Kasi (ibidem, p. 35) observed that 'Most people are forced to do research. Research in an academic world is an unequivocal criterion for promotion. This ... leaves little option for individuals; "publish or perish" is the law of the academic world'. With such a perspective it is difficult to see any possibility for the development of Rogers' 'fully functioning person' concept or Macmurray's goal of 'knowing ourselves completely;' Kasi (ibidem) did, however, go on to identify tasks for the researcher which include: consideration of the motive for the research, and advice to 'try to do research for the sake of inquisitiveness ... and personal development.' How that is achieved though, is not explicit. The pursuit of externally-imposed intellectual enquiry encourages a disconnect between the learner and the thing learned. It is apparent that discovery comes from the passionate pursuit of knowledge, often driven by an obsession related to experience; this is evident, though not explicit, in the study of religion, particularly with researchers writing from an emic perspective. The work of many theologians and religious writers can be easily traced to their pursuit of justice or understanding born from personal experience. Passionate curiosity most often has a personal experiential trigger, whether unconsciously or explicitly acknowledged, but to gain a deep understanding of religion the learner's own reasons for that passionate curiosity must be acknowledged and explored.

Rather than adopting a divided-life approach to research, the learner's own conscious (auto)ethnography can indeed be a valuable contribution to 
the overall study. This enables the research process to develop a new type of dialogical discourse with the potential to open up fresh insights, and personally invests the learner in his/her research as per Langellier's evaluation of the effect of personal narrative. It raises the question of the efficacy of unembodied overarching academic meta-narratives in contemporary research and opens up the possibility of bringing autoethnographical discourse into the research arena:

The voice needs a body which personal narrative furnishes. From social life, a complementary movement applies: the body needs a voice to resist the colonising powers of discourse... Personal narrative responds to both the wreckage and the reflexivity of postmodern times when master narratives disintegrate. (Langellier, 1998, p. 207)

Perhaps then, in dialogue with Macmurray, Rogers and reflective approaches to learning, an autoethnographical method can be one way of reembodying education from the divided-life to the integrated learner. The core ideals of autoethnography are to connect 'personal (insider) experience, insights and knowledge to larger (relational, cultural, political) conversations, contexts and conventions,' so as to create 'nuanced, complex, and specific accounts of personal/cultural experience' (Adams et al., 2015, p. 25). Autoethnography comprises a number of distinguishing characteristics which include: (1) purposefully commenting on/critiquing culture and cultural practices, (2) making contributions to existing research, (3) embracing vulnerability with purpose, and (4) creating a reciprocal relationship with audiences in order to compel a response (Jones et al., 2013, p. 22).

Unlike Jankowitz's premise that 'your knowledge only has value in relation to other people's,' autoethnography values the researcher as a rich repository of research data. This blending of observation of culture together with personal narrative and insights offers the opportunity for dialogue between the subject being researched and the learner. As De Munck (2000, pp. 1-2) asserted, 'Culture requires our presence as individuals. With this symbiosis, self and culture together make each other up and, in that process, make meaning.'

This approach requires a third dimension, which Chang (2008, p. 26) identified as 'others' - a concept which can take on many forms. Searching for connections between self and others is part of the autoethnographical conversation; seeking out the 'others' helps both 'understand our common identities' and enables us to see ourselves 'more clearly by contrast' (ibidem, p. 134). 
It is effectively research on our own relationships and the connections we observe with others in culture and community and, as such, it necessarily remains dialogical. This is potentially an exciting development for learning; the absence of 'undebatable conclusions' (Ellis \& Bochner, 2000, p. 744) allows for 'a resistance to finality and closure [and] reflects a conception of the self (and society) as relational and processual' (Anderson \& Glass-Coffin, 2013, pp. 78-79). It opens up the possibility of new insights into both the subject and the self, whereby the lonely, isolated learner finds relationship-in-research, which transcends the divided-life method and unlocks a critically reflexive, multi-dimensional discourse. Here, traditional research methods, and the individual experiences of both the learner and others, can produce additional understanding.

Autoethnography, while not widely recognised in the canon of academic methodology, ${ }^{4}$ is being increasingly recognised as having a qualitative role to play in research. Chang argued that the autoethnographic method is a valuable tool in the study of culture because:

The reading and writing of self-narratives provides a window through which self and others can be examined and understood ... [and that] ... telling one's story does not automatically result in the cultural understanding of self and others, which only grows out of in-depth cultural analysis and interpretation. (Chang, 2008, p. 13)

This ability to link the self with the social can lead to both cross-cultural understanding and coalition-building between self and others and, importantly, to transformation through self- understanding (ibidem, p. 57). Autoethnography is increasingly seen (though not explicitly acknowledged) in memoirs and autobiographies which are themselves used within academic discourse across social, cultural, and political boundaries. ${ }^{5}$ Chang noted the benefits of autoethnography for the religious realm, pointing to the 'self-exposure' of mind in the narratives of some Christian scholars throughout the centuries ${ }^{6}$

${ }^{4}$ Critics of autoethnography refute that it is scholarship, arguing that 'personal, autobiographic, and aesthetic work cannot be assessed for its explanatory power, scholarly insight, or ability to cultivate social change' and that it sacrifices the analytic purpose of research through inclusion of storytelling and first-person narrative (Adams et al., 2015, p. 99).

${ }^{5}$ For examples see Chang (2008, p. 152ff).

${ }^{6}$ Chang lists among others: St Augustine ( $4^{\text {th }}$ Century), Margery Kempe ( $15^{\text {th }}$ Century), Thomas Merton (20 $0^{\text {th }}$ Century), Sue Monk Kidd ( $21^{\text {st }}$ Century). 
as a form of witness, which informs objective discourse in many academic theological and religious studies' narratives. Biographical accounts form part of the research dialogue with which the learner can test his/her own experience in relation to that of others in similar and different times and contexts. The study of religion is about making connections with that which is not easily observable, but is common to many individuals and societies; and with the developing of 'cultural emphasis on self and self-revelation', which can have the effect of trivialising so much of religion, autoethnography offers the chance to study it in fresh ways which seek to make connections between the self and the thing studied in an ethical, interpretative and reflective way (Ellis \& Adams, 2014, p. 257).

\section{Conclusion}

For me, the experience of HE both as learner and tutor has led to the realisation that there is indeed a considerable disconnect in learning which still values rationalism over emotion, and this has led to a crisis of loneliness and alienation for learners at all levels. I have argued that, to alleviate this, learning in HE may benefit from engagement with Macmurray's concept of education as being holistic and involving both head and heart, that 'one cannot really know about anything unless one first knows it', and Rogers' theory of the 'fully functioning person' who is ever-changing and developing. Learning in HE should be transformational, both in terms of the subject being studied and, importantly, of the individual. Reflective learning in HE goes part of the way towards addressing the issue, but it is still largely grounded in the intention to transform understanding of the thing being studied, and does little to alleviate the loneliness of the divided life. To this end I propose the inclusion of an autoethnographic methodology as one means of breaking down barriers between divided-self learning and personal growth; perhaps making use of autoethnographic methods in all forms of HE learning - from undergraduate work to the highest levels of research - can indeed improve learning and research and reduce the alienation of the learner, especially in relation to religion. As Thomas Merton, a trappist Monk and spiritual writer, observed in his reflection on his earlier autobiography:

Perhaps if I were to attempt this book today, it would be written differently. Who knows? But it was written when I was still quite young, and that is the way it remains. The story no longer belongs to me. ... Therefore, most honourable 
reader, it is not as an author that I would speak to you, not as a storyteller, not as a philosopher, not as a friend only. I seek to speak to you, in some way, as your own self. Who can tell what this may mean? I myself do not know, but if you listen things will be said that are perhaps not written in this book (Merton, [1948] 1998, pp. xvii-xviii).

\section{References}

Adams, T. E., Jones, S. H. \& Ellis, C. (2015). Autoethnography: Understanding Qualitative Research. Oxford: Oxford University Press.

Anderson, L. \& Glass-Coffin, B. (2013). I Learn by Going: Autoethnographic Modes of Inquiry. In S.H. Jones, T.E. Adams \& C. Ellis (Eds.), Handbook of Autoethnography (pp. 57-83). Walnut Creek, California: Left Coast Press.

Archer, L. (2008). Younger academics' constructions of 'authenticity', 'success' and professional identity. Studies in Higher Education, 33(4), 385-403.

Bourner, T. \& Greener, S. (2016). The Research Journey: Four Steps to Success. In T. Greenfield \& S. Greener (Eds), Research Methods for Postgraduates. Chichester: Wiley.

Bradley, H. (2017). 'Should I stay or should I go?': Dilemmas and decisions among UK undergraduates. European Educational Research Journal, 16(1), 30-44.

Bristow, W. (2017). Enlightenment. In E. N. Zalta (Ed.), The Stanford Encyclopedia of Philosophy (Fall 2017 Edition). Retrieved March 8, 2020, from https://plato. stanford.edu/cgi-bin/encyclopedia/archinfo.cgi?entry=enlightenment.

Brockbank, A. \& McGill, I. (1998). Facilitating Reflective Learning in Higher Education. Buckingham: Society for Research into Higher Education and Open University Press.

Chang, H. (2008). Autoethnography as Method. Walnut Creek, California: Left Coast Press.

De Munck, V. (2000). Culture, Self and Meaning. Prospect Heights, IL: Waveland Press.

Dewey, J. (1916). Democracy and Education. London: Macmillan.

Ellis, C. \& Adams, T. E. (2014). The Purposes, Practices, and Principles of Autoethnographic Research. In P. Leavy (Ed.), The Oxford Handbook of Qualitative Research. Oxford: Oxford University Press.

Ellis, C., Adams, T. E. \& Bochner, A.P. (2010). Autoethnography: An Overview [40 paragraphs]. Forum Qualitative Sozialforschung / Forum: Qualitative Social Research, 12(1), Art. 10, http://nbn-resolving.de/urn:nbn:de:0114-fqs1101108. 
Ellis, C. \& Bochner, A. P. (2000). Autoethnography, personal narrative, and personal reflexivity. In N. K. Denzin \& Y. S. Lincoln (Eds.), Handbook of qualitative research (2 ${ }^{\text {nd }}$ ed.) (pp. 733-768). Thousand Oaks, CA: Sage.

Ellis, C. \& Bochner, A. P. (1992). Telling and performing personal stories: the constraints of choice in abortion. In C. Ellis \& M. Flaherty (Eds.), Investigating subjectivity: Research on lived experience (pp. 79-101). Newbury Park, CA: Sage.

Gannon-Leary, P., Fontainha, E. \& Bent, M. (2011). The loneliness of the long distance researcher. Library Hi Tech, 29(3), 455-468.

Hortulanus, R., Machielse, A. \& Meeuwesen, L. (2006). Social Isolation in Modern Society. London and New York: Routledge.

Jones, S. H., Adams, T. E. \& Ellis, C. (2013). Handbook of Autoethnography. Walnut Creek, California: Left Coast Press.

Kasi, P. M. (2009). Research, What, Why and How?: A Treatise from Researchers to Resarchers. Bloomington: AuthorHouse.

Langellier, K. (1998). Voiceless bodies, bodiless voices: The future of personal narrative Performance. In S. J. Dailey (Ed.), The future of performance studies: Visions and revisions (pp. 207-213). Annandale, VA: National Communication Association.

Langellier, K. (1999). Personal narratives: Perspectives on theory and research. Text and Performance Quarterly, 9, 243-276.

Lantieri, L. (Ed.) (2001). Schools with Spirit: Nurturing the Inner Lives of Children and Teachers. Boston, Massachusetts: Beacon Press Books.

Lea, S. J., Stephenson, D. \& Troy, J. (2003). Higher Education Students' Attitudes to Student Centred Learning: Beyond 'educational bulimia'. Studies in Higher Education, 28(3), 321-334.

Macmurray, J. (1935). Reason and Emotion. London: Faber and Faber.

Merton, T. (1998). The Seven Storey Mountain: fiftieth anniversary edition. Boston: Houghton Mifflin.

Moon, J. (2004). A Handbook of Reflective and Experiential Learning: Theory and Practice. London and New York: RoutledgeFalmer.

O'Grady, K. (2010). Researching religious education pedagogy through an action research community of practice. British Journal of Religious Education, 32(2), 119-131.

O’Neill, G. \& McMahon, T. (2005). Student-Centred Learning: What does It Mean for Students and Lecturers? In: O’Neill, G., Moore, S., McMullin, B. (Eds.), Emerging Issues in the Practice of University Learning and Teaching (pp. 27-36). Dublin: AISHE. 
Pancer, S. M., Hunsberger B., Pratt, M. W. \& Alisat, S. (2000). Cognitive complexity of Expectations and Adjustment in the First Year. Journal of Adolescent Research, 15(1), 38-57.

Rogers, C. R. (1963). The Concept of the Fully Functioning Person. Psychotherapy: Theory, Research and Practice, 1(1), 17-26.

Rogers, C. (1969). Freedom to Learn. Columbus, Ohio: Charles E. Merrill Publishing Company.

Schön, D. ([1983], 1991). The reflective Practitioner: How professionals think in action. New York and Oxon: Ashgate.

Sadeghi Bahmani, D., Faraji, P., Faraji, R., Lang, U.E., Holsboer-Trachsler, E. \& Brand, S. (2018). Is emotional functioning related to academic achievement among university students? Results from a cross-sectional Iranian sample. Braz J Psychiatry, 40(3), 290-295. doi:10.1590/1516-4446-2017-2434

Sibai, O., Figueiredo, B. \& Ferreira, M. C. (2019). Overworked and isolated: the rising epidemic of loneliness in academia. Retrieved January 12, 2020, from https://theconversation.com/overworked-and-isolated-the-rising-epidemic-of-loneliness-in-academia-110009.

Spry, T. (2001). Performing Autoethnography: An Embodied Methodological Praxis. Qualitative Inquiry, 7(6), 706-732.

Stone, T., Levett-Jones, T., Harris, M. \& Sinclair, P. M. (2010). The genesis of 'the Neophytes': a writing support group for clinical nurses. Nurse Education Today, 30(7), 657-661.

Vighnarajah, S. \& Lim, S. Y. J. (2018). Influence of Student Isolation on Students' University Learning Experiences: Perspectives of Academic, Social and Psychological Development. SHS Web of Conferences, 53, 05005.

Weiss, R.S. (1973). The Experience of Emotional and Social Isolation. Cambridge, MA: The MIT Press.

Wenger, E., McDermott, R. A. \& Snyder, W. (2002). Cultivating Communities of Practice: A Guide to Managing Knowledge. Boston, MA: Harvard Business School Press. 